\title{
光インターコネクション用超高速VCSEL
}

\author{
阿南 隆由 \\ NEC ナノエレクトロニクス研究所（５20-0833 滋賀県大津市晴嵐2-9-1）
}

\section{High-Speed VCSELs for Optical Interconnections}

\author{
Takayoshi ANAN \\ Nano Electronics Research Laboratories, NEC corporation, 2-9-1 Seiran, Otsu, Shiga 520-0833
}

(Received April 1, 2009)

\begin{abstract}
As optical interconnections and networks evolve toward higher capacity, a need exists for faster VCSELs. However, higher speed operation of VCSELs requires higher current density, which shortens the device lifetime. To solve this problem, we present a design guide for high-speed VCSELs and demonstrate the high-speed and high-reliable characteristics of our developed InGaAs-based 1.1- $\mu \mathrm{m}$ VCSELS.
\end{abstract}

Key Words: VCSEL, High-speed modulation, High-reliability, InGaAs, Tunnel junction

\section{1.はじめに}

情報化社会の進展に伴って, サーバ, ルータやスー パーコンピュータ等の情報機器の処理容量が増大し, 機 器内で用いられる信号伝送も高速・大容量化している。 これまで，この信号伝送には主に電気伝送が用いられて きたが，伝送速度が上がるほど信号歪みやクロストーク 等の影響により伝送可能な距離が短くなる。このため, 光による信号伝送(光インターコネクション)への期待が 高まっている.

このように光インターコネクションの必要性は増して いるが, 電気伝送に取って代わるには幾つかの要件を満 たす必要がある。 それらは, 小型・高密度実装, 低消費 電力, 低コスト性である。これらを満たす光インターコ ネクション用の光源として面発光レーザー (VCSEL) が ある. VCSELは, 端面発光型の半導体レーザーに比べ て活性層体積が一桁程度小さいので, 低しきい電流で発 振し, 数mA程度の小さな電流でも高速な信号変調がで きる。この動作電流が小さく低消費電力であることと， 基板から垂直にレーザー光を取り出せるという特長か ら，小型・高密度実装1)が可能となる。またVCSELは, 製造プロセスの容易性, 高歩留まり性等に起因した低コ スト性も有している。このような点からVCSELは, マ ルチモードファイバ (MMF) と組み合わせて数 $\mathrm{Gbps}$ の短 距離デー夕通信用光源としてすでに広く普及し, 高速 $10 \mathrm{Gbps} / \mathrm{ch}$ 品も実用域に達しつつある。また，比較的接 続距離の長いノード(筐体)間の伝送では, Infiniband等 の規格に準拠した光インターコネクションが適用される
ようになってきている.

しかし, 近年スーパーコンピュータ内の光インターコ ネクション2)や100ギガビットイーサネット用の光源と して, $20 \mathrm{Gbps}$ あいはそれ以上の伝送速度への対応が 求められている。ささらには超短距離 (VSR) $40 \mathrm{Gbps}$ 光伝 送システム用光源としてVCSELを利用することも検討 されており，これに対応するには従来と比べて大幅な変 調速度の向上が必要となる。一般に, 高速化には電流密 度の増加が有効であるが, VCSELでは電流注入時に活 性層温度が大きく上昇するため, これまで電流密度を増

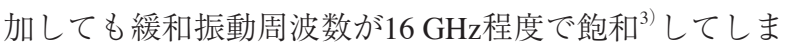
い, 30 Gbps以上の高速伝送を困難にしていた。 また素 子の寿命は電流密度の増加とともに低下するため, 信頼 性も大きな問題)となっていた。

そこで本稿では，特に動作速度が $20 \mathrm{Gbps}$ 超えるよ うな超高速VCSELの開発に関し，その設計指針，酸化 狭窄型VCSEL構造による30 Gbps-100 mエラーフリー伝 送, $100{ }^{\circ} \mathrm{C}-25 \mathrm{Gbps}$ 高温・高速動作や高信頼性の実現, またトンネル接合型VCSEL構造による高速性改善㧍よ び40 Gbpsエラーフリー動作等の成果について述べる.

\section{2. 超高速VCSELの設計指針}

\section{1 活性層材料の検討}

一般的なVCSELの活性層は, 発振波長 $850 \mathrm{~nm}$ となる GaAs/AlGaAs量子井戸構造で構成され，LAN規格に準拠 したデータコム用途として広く普及している，発振波長 に850 nmが用いられた理由の一つは, 低速1 Gbps程度以 
下の受光素子に低コストなSi-PD (Photo Diode)を用いる ことができることが挙げられる，現在もこの流れに沿 い, 高速10 GbpsのVCSELでも850 nm帯が標準化されて いるが，この速度ではSi-PDを使用することができず GaAs-PDとなるため, この波長を用いるメリットは薄れ ている，一方，10 Gbpsを超える高速化を実現するため， 電流密度を高くして光子密度をあげることが通常おこな われるが, 電流密度と素子寿命はトレードオフの関係 ${ }^{4}$ にあるため，素子の信頼性に問題が生じてくる，そこ で, 超高速VCSELの開発においては, 波長の制約を超 えて, より高い微分利得, より高い信頼性を実現可能な 材料系をまず選択すべきと考えた

この高速性と高信頼性を両立させるという観点から， InGaAs歪量子井戸をVCSEL活性層に採用した。本材料 系は, (1)量子井戸の圧縮歪の効果により高い微分利得 ${ }^{5)}$ が得ることができ, 高速化に有利である。事実, 本活性 層を用いたFP-LDにおいて40 GHzの帯域が報告(6) されて いる. (2)InGaAsはGaAsと比べて転位増殖速度が非常に 遅〈7), 且つ, 活性層領域を $\mathrm{Al}$ フリーと出来ることから 高信頼性が期待できる。 さらに, (3)高密度実装の観点か らは, 発振波長が1.1 $\mu$ m带であるためGaAs基板を通し て裏面から光を取り出せる形態が可能となり, 電気と光 の入出力を空間的に分離出来るため実装密度を増大させ ることができる。このようにInGaAs量子井戸は多くの メリットを有しており，このような材料系からのアプ ローチは，標準化という越えるべき壁はあるが, 高速性 と信頼性を両立させる上で重要と考えている.

波長を $1.1 \mu \mathrm{m}$ 帯とした理由は, 高速性の観点からはIn 組成が多い方(より長波の方)が良いが，一方でIn組成が 多すぎると歪臨界膜厚を越え結晶品質が低下するため, その最適なIn組成として波長1.1 $\mu \mathrm{m}$ 帯とした。ささらに， 本材料系の量子井戸層と, 引張性の歪を有する GaAsP障 壁層とを組み合わせると, 活性層全体を歪補償量子井戸 構造にすることが可能である。この歪補償量子井戸構造 では, 歪み構造として安定化が図れるだけでなく, 伝導 帯バンド不連続值もGaAs障壁層と比べて大きくなるの で, 電子の閉じ込めが強くなり, 高温環境下での動作も 有利 ${ }^{8)}$ となる。

以上の材料・構造の検討は, 端面型レーザーでも通じ る話であるが, 次にVCSELの高速化に特有な設計指針 に関して考える。

\subsection{VCSEL構造の検討}

VCSELの変調帯域を制限する要因としては, 通常の 端面型半導体レーザーと同じように, 内因性の要因 $(I$ $(f))$ として緩和振動周波数 $\left(f_{r}\right)$ とダンピング定数 $\left(\gamma=K f_{r}^{2}\right.$ $\left.+\gamma_{0}\right)$ が, 外因性の要因 $(P(f))$ として素子の電気的制限 (CR 時定数) がある. 式で表すと, 変調の伝達関数を $M$ (f) とすると,

$$
\begin{aligned}
|M(f)|^{2} & =|I(f)|^{2} \times|P(f)|^{2} \\
& =\left(\frac{f_{r}^{4}}{\left(f_{r}^{2}-f^{2}\right)^{2}+(\gamma / 2 \pi)^{2} f^{2}}\right) \times|P(f)|^{2}
\end{aligned}
$$

となる ${ }^{9)} . P(f)$ は，素子の抵抗 (DBR (Distributed Bragg Reflector) 抵抗, 活性層近傍の抵抗) や容量 (メサ容量, パッド容量)によって決まり，その等価回路モデルによ り表式が異なる。通常VCSELの抵抗は数十から数百 オームと高く, CR 時定数の低減は, 主にメサ部の容量C を低減することで対応しており，メサの小径化，メサ外 周部へのイオン注入などにより $P(f)$ の帯域幅を $20 \mathrm{GHz}$ 以上にすることが可能である。一方, 内因性の要因 $I(f)$ では帯域幅を決める要因として $f_{r}$ と $\gamma$ があるが, VCSEL の高速化を困難にしている要因は主として $f_{r}$ でり， (2)式のように表せる ${ }^{10)}$.

$$
f_{r}=\frac{1}{2 \pi} \sqrt{\frac{\partial g}{\partial n} \frac{v_{g} N_{p}}{\tau_{p}}}=\frac{1}{2 \pi} \sqrt{\frac{\partial g}{\partial n} \frac{v_{g} \eta_{i}\left(I-I_{t h}\right)}{q V_{p}}}
$$

この式からわかるように $f_{r}$ は, 微分利得 $(\partial g / \partial n)$, 光子 密度 $\left(N_{p}\right)$, 共振器の光子寿命 $\left(\tau_{p}\right)$ 等に依存し, 素子に流 す電流值を上げると光子密度(光出力)が上がり $f_{r}$ も単調 に増大する。しかしVCSELでは素子の電気抵抗や熱抵 抗が高いので, 電流注入と共に活性層温度が大きく上昇 する。 この活性層温度の上昇は, 微分利得の低下や内部 量子効率を低下させ，その結果として $f_{r}$ の注入電流によ る伸びを飽和させてしまう。 $f_{r}$ の改善には，素子の電気 抵抗や熱抵抗を下げることで温度上昇自体を抑制する方 法や, 室温での微分利得を大きくしたりモード体積 $\left(V_{p}\right)$ を小さくすることで変調の効率を高め, 温度上昇による 飽和が顕著になる前に高い $f_{r}$ を得る方法等がある.

以下では具体的に，素子のCR時定数低減と $f_{r}$ の飽和を 抑制することを考慮して設計した， 2 種類の超高速 VCSELについて説明する。

\section{3. 酸化狭窄型VCSEL}

Fig. 1は酸化狭窄型VCSELのデバイス構造である. $\lambda$ 共振器の中心に厚さ $5 \mathrm{~nm}$ の $\operatorname{In}_{0.3} \mathrm{GaAs}$ 井戸層と $10 \mathrm{~nm}$ の GaAs障壁層からなる3層のMQW活性層が配置されてい る。障壁層には, ダンピング定数を低減し最大変調帯域

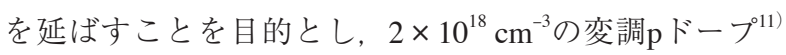
を施した。 DBRはn側が44.5ペアの GaAs/ $/ \mathrm{Al}_{0.9} \mathrm{GaAs}, \mathrm{p}$ 側 が $\mathrm{Al}_{0.98} \mathrm{GaAs}$ 層, 23ペアの $\mathrm{GaAs} / \mathrm{Al}_{0.9} \mathrm{GaAs}$ 及びGaAsコン タクト層から構成され, 上記 $\mathrm{Al}_{0.98} \mathrm{GaAs}$ 選択酸化して 電流狭窄構造を形成している。メ径は熱抵抗低減を目 的として比較的大きな $33 \mu \mathrm{m} \phi$ とし，そのメサ容量低減 のため中央 $14 \mu \mathrm{m} \phi$ 以外をプロトン注入により高抵抗化

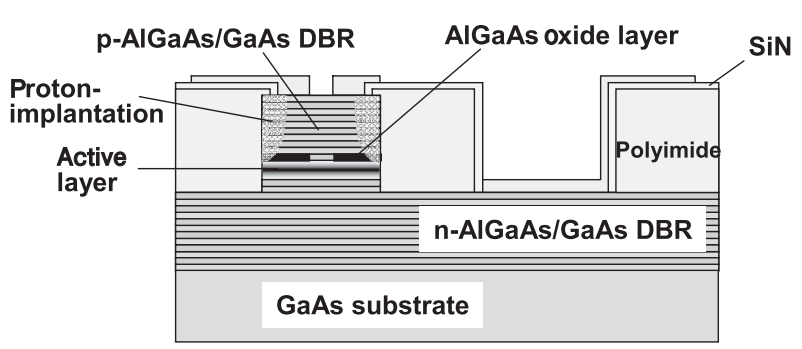

Fig. 1 Schematic of device structure of oxide-confined VCSEL. 
した。また，メサ構造はパッド容量低減のためポリイミ ドによって埋め込んでいる, 試作素子において, 酸化狭 窄径6.9 $\mu \mathrm{m} \phi$ の素子のしきい值電流は室温で $0.4 \mathrm{~mA}$, ス

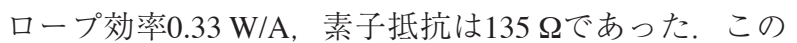
素子の小信号変調特性は, バイアス電流7 mAにおいて, $20 \mathrm{GHz}$ の変調帯域 $\left(3 \mathrm{~dB}\right.$ 帯域) が得られた ${ }^{12)}$ 。等価回路モ デルによる解析の結果, 等価回路の $3 \mathrm{~dB}$ 帯域が $24 \mathrm{GHz}$, $f_{r}$ が16 GHzと見積もられ，本素子の变調帯域を制限して いるのは主に, 自己発熱により飽和した $f_{r}$ であると推察 される。

また，この面発光レーザーを用いて30 Gbps光伝送実 験を行った。VCSELから出射された信号光は, コア径 $32 \mu \mathrm{m} \phi$ のMF $(\mathrm{GI}-32)$ を伝播し，PD-TIAで構成される レシーバで受光される。ここで用いた受光素子は, $1.1 \mu \mathrm{m}-\mathrm{VCSEL}$ 対応して開発しており，InP基板上の裏 面入射型PIN-PDである。この素子では, $-1 \mathrm{~V}$ 印加時に $20 \mathrm{GHz}$ の $3 \mathrm{~dB}$ 帯域が得られている. Fig. 2 に, 本伝送実 験におけるビットエラーレート特性と $100 \mathrm{~m}$ 伝送後のア イ波形を示す.VCSELの駆動条件はバイアス電流7 mA, 変調電圧 $0.65 \mathrm{Vp}-\mathrm{p}$ で, PDの入力光強度は $0 \mathrm{dBm}$ であっ た. $100 \mathrm{~m}$ 伝送後も良好なアイ開口が得られ，30 Gbps工 ラーフリー伝送が確認 ${ }^{13)}$ された。このときの伝送ペナル ティは $2 \mathrm{~dB}$, ファイバの伝播損失は $1 \mathrm{~dB} ゙$ あった。 $\operatorname{MMF}(\mathrm{GI}-32)$ の波長1.07 $\mu \mathrm{m}$ での帯域幅は2000 MHz·km であり，このため $100 \mathrm{~m}$ 伝送時に伝送ペナルティが生じ たと考えている。 $30 \mathrm{Gbps}-100 \mathrm{~m}$ 伝送の実現は, この超高 速光インターコネクションが, 筐体間伝送でも適用可能 であることを意味する

さらに酸化狭窄型VCSELの高温での動作を目的とし て障壁層を $\mathrm{GaAs}_{0.8} \mathrm{P}_{0.2}$ とした素子を作製した ${ }^{8)}$ 。高温下に おいて帯域が低下する原因としては，電子の障壁層への リークが挙げられるが，障壁層を GaAsPとすることによ り，井戸層との伝導帯バンド不連続量 $(\Delta \mathrm{Ec})$ を約 $100 \mathrm{meV}$ 増加し, 高温下でのリークを低減させることが

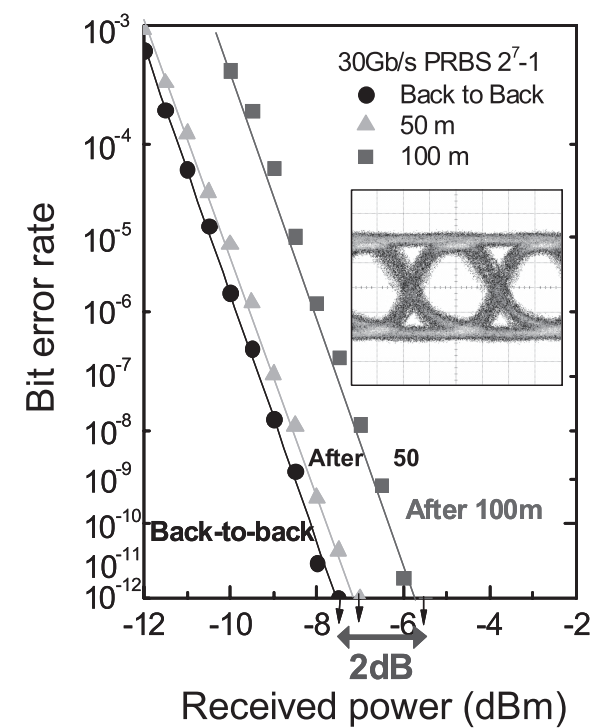

Fig. 2 Measured eye diagrams and bit error rates under 30 Gbit/s transmission rate after back-to-back, $50 \mathrm{~m}$, and $100 \mathrm{~m}$ transmission.

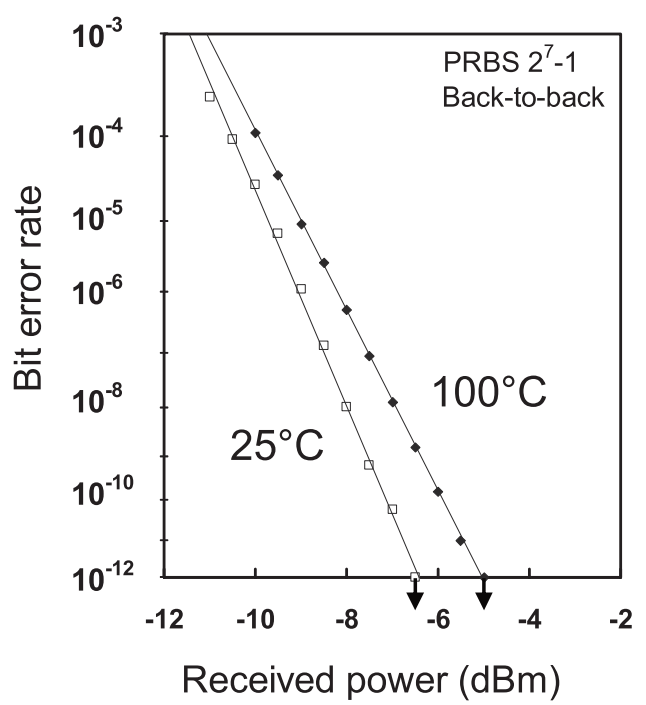

Fig. 3 Measured bit error rates under $25 \mathrm{Gbit} / \mathrm{s}$ transmission rate at $25^{\circ} \mathrm{C}$ and $100{ }^{\circ} \mathrm{C}$.

できると期待できる。実際, $\mathrm{GaAs}_{0.8} \mathrm{P}_{0.2}$ バリア層を用い たVCSELの最高動作温度は $219^{\circ} \mathrm{C}$ と推定でき, GaAsバ リア層のものと比べて約 $60 \sim 70{ }^{\circ} \mathrm{C}$ ぼ高温で動作し

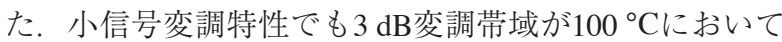
$15 \mathrm{GHz}$ あり (GaAsバリアのものは約 $10 \mathrm{GHz})$ ，高温下 での優位性が示された. Fig. $3 に 25^{\circ} \mathrm{C}$ おび $100{ }^{\circ} \mathrm{Cにお}$ ける $25 \mathrm{Gbps}$ での伝送特性 $(\mathrm{MMF}, 3 \mathrm{~m})$ を示す。 $100{ }^{\circ} \mathrm{C}$ においてもエラーフリー動作が得られた。このように $\mathrm{GaAs}_{0.8} \mathrm{P}_{0.2}$ バリア層を用いた素子では高温下において特 性上優位であることが確認された。さらにGaAsPは $\mathrm{InGaAs}$ と反対の引張歪を有するため，本活性層の平均 歪みをほぼ零とすることができ信頼性の点でも有利と期 待される. Fig. 4に, 活性層のバリア層に $\mathrm{GaAs}_{0.8} \mathrm{P}_{0.2}$ 層を 用いた酸化狭窄型VCSELのACC通電試験結果を示し た。試験条件は, $150{ }^{\circ} \mathrm{C}, 10 \mathrm{~mA}\left(\right.$ 約 $19 \mathrm{kA} / \mathrm{cm}^{2}$ の電流密 度に相当)であり，電流による自己発熱分を考慮すると， 活性層温度は約 $208{ }^{\circ} \mathrm{C}$ 算出された。 3000 時間を超えて も顕著な劣化は見られず，この材料系を用いた素子の非 常に高い信頼性が実証された。本試験の継続により平均

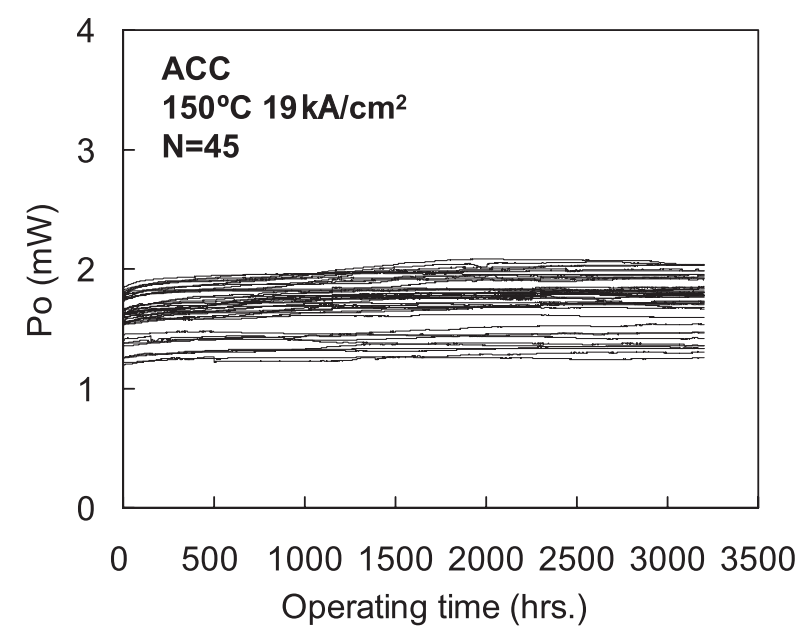

Fig. 4 Output power variation of 45 devices during accelerated life test. 
故障時間 (MTTF) を求めた結果, 10690時間と見積もら れた。一方，これまで報告されている $850 \mathrm{~nm}$ 帯10 Gbps-

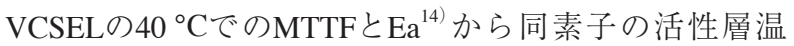

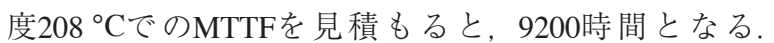
MTTFの電流依存性を考慮するとこの差はさらに広が る.このことから, $1.1 \mu \mathrm{m}$ 帯の $25 \mathrm{Gbps}$ 用素子は850 nm 帯の $10 \mathrm{Gbps}$ 用素子と同等以上の信頼性を有していると 言える.

\section{4. 埋め込みトンネル接合型VCSEL}

埋め込みトンネル接合型 (Buried tunnel junction: BTJ) VCSELでは $f_{r}$ を改善するために，素子の低抵抗化による 発熱の抑制と, モード体積の縮小による変調効率の増大 を狙っている. TJを用いると抵抗の高いp型半導体の大 部分をn型半導体に置換できるため, TJ部が十分に低抵 抗となれば, 酸化狭窄型VCSELに比べて素子抵抗を大 幅に低減できる，また，TJ構造を採用することで半導体 p-DBRに替えて，屈折率差の高い誘電体DBRを採用する ことが可能となり, p-DBR側への光のしみ出しを抑制し モード体積を小さくすることができる，このため，より 小さな電流で高速な応答が可能となる.

TJ部は，光吸収を少なくするために発振波長のエネル ギーより禁制帯幅が大きな半導体で形成する必要があ る。しかし，禁制帯幅が大きくなるほど急激にトンネル 確率が低下し抵抗が増加するため, VCSELへの適用は 主として波長1.3 $1.5 \mu \mathrm{m}$ の長波帯素子 ${ }^{15)}$ に限って検討さ れてきた。 そこで我々は, 波長 $1.1 \mu \mathrm{m}$ 帯においても, 低 光吸収と低抵抗を同時に実現可能なType-II (スタガード) 型TJの適用を提案 ${ }^{16)}$ L, TJ部の低抵抗化及びVCSEL素 子化の検討を行った。

TJ部をType-IIヘテロ界面とすることで, 電子のトンネ ルする障壁が小さくなり，トンネル確率を増大させるこ とが可能となる。 またType-II型へテロ構造であるため電 子と正孔の波動関数の空間的な重なりが小さく, 低光吸 収となる. Type-II型TJ構造として $\mathrm{p}-\mathrm{GaAsSb}_{0.12} / \mathrm{n}-\mathrm{In}_{0.15} \mathrm{GaAs}$ ヘテロ構造TJを作製し, 抵抗評価を行った。 ドーパント はp側 がC, n側 がSiであり, SIMS (Secondary Ion Mass Spectrometry)で測定した濃度はそれぞれ $1.5 \times 10^{20} \mathrm{~cm}^{-3}$, $5 \times 10^{19} \mathrm{~cm}^{-3}$ である。ゼロバイアス近傍での微分抵抗は $4.0 \times 10^{-6} \Omega \mathrm{cm}^{2}$ となり，この值は長波用TJも含めてトッ プクラスの值である。また実際のVCSEL構造において も抵抗の高いp型半導体の大部分をn型半導体に置換で き, 約 $40 \%$ の抵抗低減(Fig. 5)が確認 ${ }^{17)}$ された

次に,このType-II型トンネル接合部を適用したBTJ$\mathrm{VCSEL}^{18)}$ を試作した。その構造をFig. 6に示す。活性層 は，上記酸化狭窄型VCSELと同様に， $\mathrm{In}_{0.3} \mathrm{GaAs} / \mathrm{GaAs}-$ $3 \mathrm{MQW}$ 構造である。TJ構造は光吸収をより小さくする ため定在波の節となる位置に形成し，nスペーサ層によ り埋め込んだ。埋め込み構造にすることで電流狭窄機能 を実現した。また，素子容量低減のために，活性層周り に酸素イオン注入を施し，メサ領域はポリイミドで埋め 达んた。誘電体DBRは3ペアの $\mathrm{a}-\mathrm{Si} / \mathrm{SiO}_{2}$ からなり, 波長

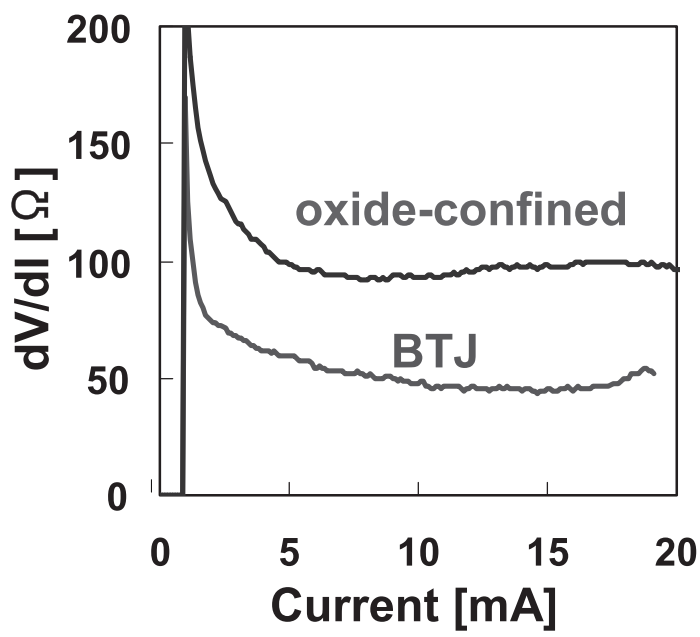

Fig. 5 Comparison of I-dV/dI characteristics for BTJVCSEL and oxide-confined VCSEL.

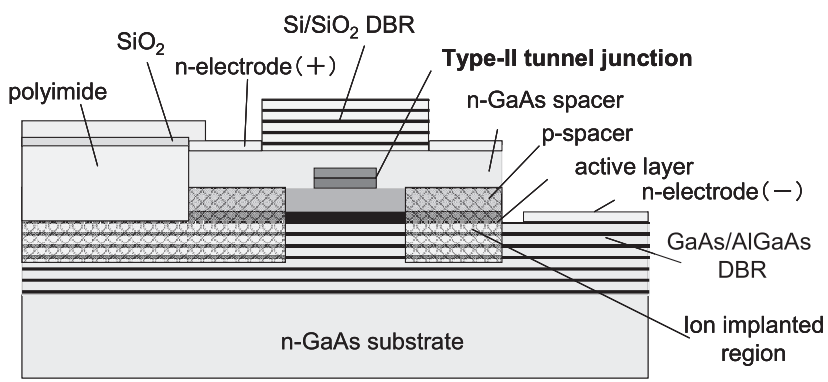

Fig. 6 Schematic of device structure of TJ-VCSEL.

$1.1 \mu \mathrm{m}$ におけるa-Siの吸収係数は約 $100 \mathrm{~cm}^{-1}$ であり DBR の反射率は $99 \%$ 以上である.

Fig. 7に電流狭窄径が5 $\mu \mathrm{m} \phi$ の素子の小信号変調特性を 示す。バイアス電流4 mAにおいて $24 \mathrm{GHz}$ の変調帯域が 得られた。この值はこれまで報告されたVCSELの直接 変調带域としては最大である。一方, 電流狭窄径が $4 \mu \mathrm{m} \phi$ の素子では, 変調帯域はCR律速のため5 $\mu \mathrm{m} \phi$ の素 子と同程度であるが, $f_{r}$ は $27 \mathrm{GHz}$ まて伸びており, BTJVCSEL構造は $f_{r}$ の改善に有効であることが明らかとなっ た。Fig. 8に，ほぼ同じ電流狭窄径を有する酸化狭窄型

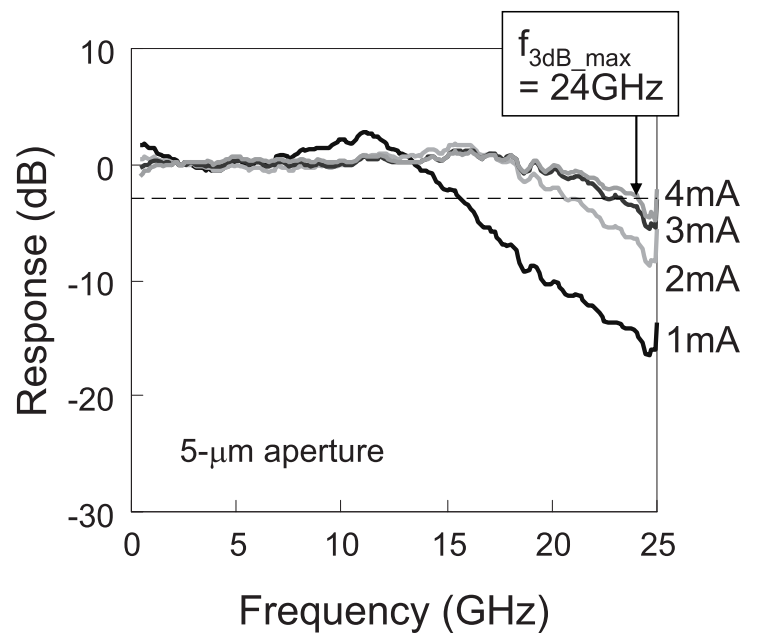

Fig. 7 Small signal modulation response of TJ-VCSEL with 5 - $\mu \mathrm{m}$ aperture diameter. 


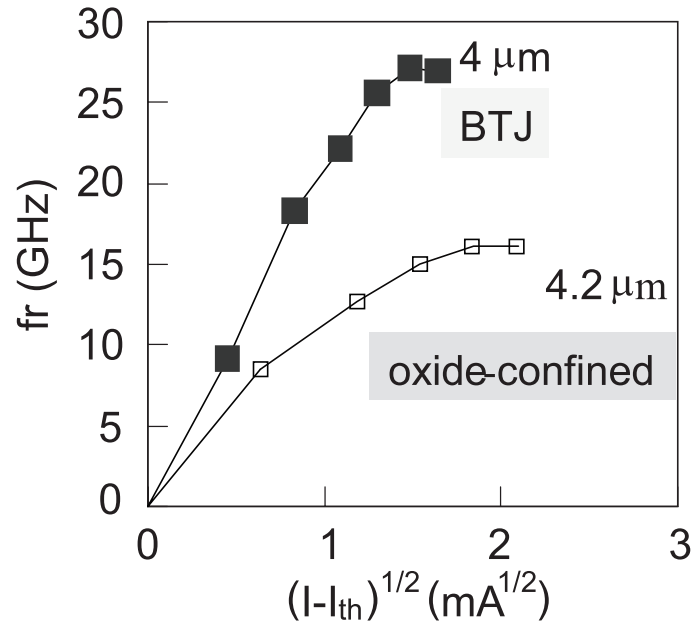

Fig. 8 Injection current dependence of relaxation frequency for BTJ-VCSEL and oxide-confined VCSEL.

VCSELとBTJ-VCSELのf $f_{r}$ の電流に対する伸びを比較し た. $f_{r}$ の注入電流に対する傾き(Dファクター) は，モー ド体積の縮小効果のためBTJ-VCSELの方が大きく, 自 己発熱による飽和が始まる前に高い $f_{r} に$ 達していること がわかる，TJ-VCSELの $f_{r}$ は，同じ活性層を有する酸化狭 窄型VCSEL $の f_{r}$ 值 $(16 \mathrm{GHz})$ に対し大幅な伸長である。こ れらの素子では，TJ部の低抵抗化は十分達成されていた が, 容量低減のための酸素イオン注入の深さ方向制御が 不十分であったため, n-DBR周りの素子抵抗が増加し た。このため, 当初期待された自己発熱低減による微分 利得飽和の抑制は実現できていない。 今後,イオン注入 条件の最適化により低抵抗化が図られれば,このトンネ ル接合型VCSELでのさらなる高速化が期待できる.

Fig.9に, BTJ-VCSELの40 Gbps駆動時のアイ波形と ビットエラーレート特性を示す。電流狭窄径は $6 \mu \mathrm{m} \phi$ で

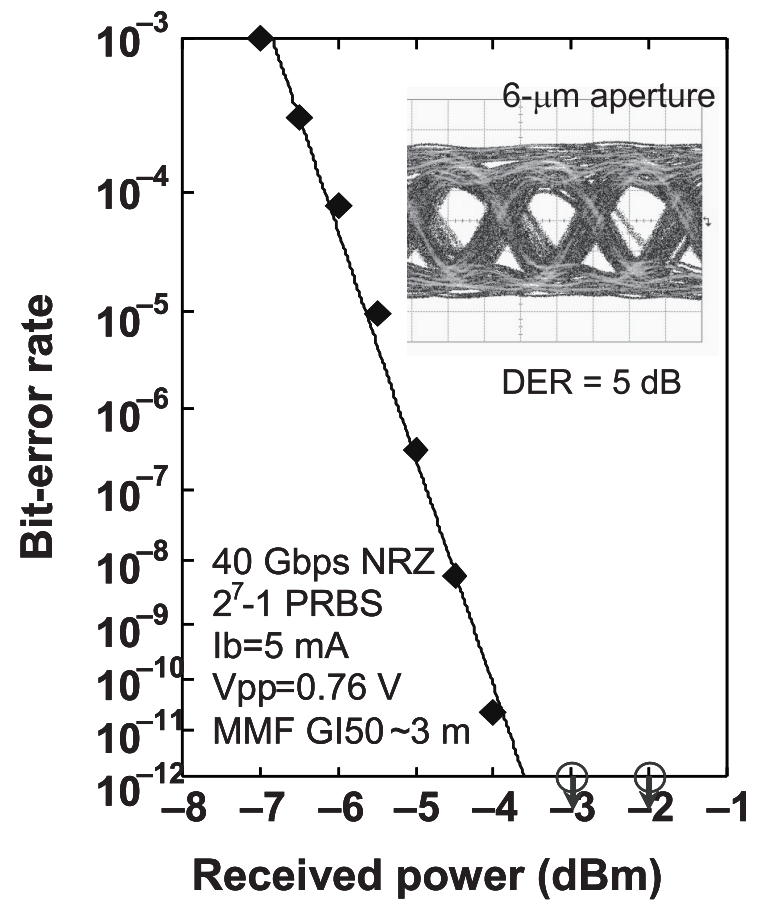

Fig. 9 Measured eye diagrams and bit error rates of the TJVCSEL under $40 \mathrm{Gbit} / \mathrm{s}$ transmission rate.
ある.VCSELの駆動条件はバイアス電流7 mA, 変調電 圧 $0.76 \mathrm{Vp}$-pで消光比は $5.3 \mathrm{~dB}$ であった。受光素子は, 酸 化狭窄型VCSELの時と同じ，帯域幅 $20 \mathrm{GHz}$ のものを用 いたが，良好なアイ開口が得られ，直接変調VCSELに おいて40 Gbpsでのエラーフリー特性が確認19)された。

\section{5. まとめと今後の展望}

高速性と高信頼性を両立させるために，活性層に $\mathrm{In}_{0.3} \mathrm{GaAs}$ 歪量子井戸を採用した波長1.1 $\mu \mathrm{m}$ 帯の超高速 VCSELを紹介した。酸化狭窄型構造に打いては，変調 带域20 GHz，30 Gbps-100 mのエラーフリー動作を実証 した。この素子の帯域制限要因は, 主として自己発熱に よる微分利得の低下である。この課題を解決するため に, 素子の高速化と低抵抗化が両立出来るBTJ-VCSEL を試作した。波長1.1 $\mu \mathrm{m}$ 帯での低抵抗トンネル接合を実 現するため, Type-II型TJ構造を提案し, 抵抗值 $4.0 \times 10^{-6} \Omega \mathrm{cm}^{2}$ を実現した。このTJを適用したVCSELに 拝いて, 変調带域 $24 \mathrm{GHz}$, 緩和振動周波数 $f_{r}=27 \mathrm{GHz}$, 及び，40 Gbpsエラーフリー動作を実証した。この高速 化は，主に，モード体積の縮小効果によるものと考元ら れ，素子抵抗の低減により更なる高速化が期待出来る.

一方，高速20 Gbpsを越えるVCSELは，850 nm帯に㧈 いても近年研究が活発化している。.P側DBRの抵抗低減 やテーパ型の酸化電流狭窄層を用いて, メサ容量の低減 と電流狭窄径の小開口径化 ${ }^{20}$ を行ったり，活性層に $10 \%$

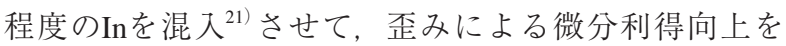
図ったりして30〜35 Gbps程度の高速化を実現してい る。この波長帯の主なメリットは, これまでのVCSEL の標準波長であるため, VCSEL以外の光部品もこの波 長帯で入手容易である点と, 従来の装置からの上位互換 が容易であるという点である.

一方で今回紹介したような $1 \mu \mathrm{m}$ 帯のVCSELでは, 既 に述べたような高性能性(高速, 高信頼性, 高温動作, 高効率性) や, 裏面出射化による高密度実装性のほか, ファイバの材料分散が $850 \mathrm{~nm}$ 光に比べて約 $1 / 3$ と小さい ためVCSELのスペクトル幅仕様の緩和や，アイセーフ ティ面での条件緩和などが期待できる，以上の上うな点 から, $1 \mu \mathrm{m}$ 帯VCSELは, 今後の光インターコネクショ ン用光源の要求に適合して㧍り,VCSELの新しい波長 標準になりうると考えている.

光源に対する超高速，低消費電力，且つ，低コストの 要求は, スーパーコンピュータのようなハイエンド用途 向けのみならず, $100 \mathrm{Gbps}$ LAN等においても拡大し, 超高速VCSELへの期待はさらに高まるであろう。

\section{謝 辞}

本研究の一部は, 文部科学省の委託研究「将来のスー パーコンピューティングのための要素技術の研究開発プ ロジェクト」(2005-2007年度)の成果である。また共同研 究に执いて日頃からご指導頂く, 東工大小林 功郎教授 に感謝致します。 


\section{参考文献}

1) C.-K. Lin, A. Tandon, K. Djordjev, S. W. Corzine, and M. R. T. Tan: IEEE J. Sel. Topics Quantum Electron. 13 (2007) 1332.

2) 佐藤 達夫：応用物理 76 (2007) 1232.

3) K. L. Lear and A. N. Al-Omari: Proc. SPIE 6484 (2007) 16.

4) B. M. Hawkins, R. A. Hawthorne III, J. K. Guenter, J. A. Tatum, and J. R. Biard: Proc. 52nd Electron. Components and Technol. Conf., San Diego, May, 2002 p. 540.

5) T. Aggerstam, R. Marrcks Von Wurtemberg, C. Runnström, and E. Choumas: Proc. SPIE 4649 (2002) 19

6) S. Weisser, E. C. Larkins, K. Czotscher, W. Benz, J. Daleiden, I. Esquivias, J. Fleissner, J. D. Ralston, B. Romero, R. E. Sah, A. Schonfelder, and J. Rosenzweig: IEEE Photon. Tech. Lett. 8 (1996) 608

7) R. G. Waters, D. P. Bour, S. L. Yellen, and N. F. Ruggieri: IEEE Photon. Tech. Lett. 2 (1990) 531.

8) H. Hatakeyama, T. Akagawa, K. Fukatsu, N. Suzuki, K. Tokutome, K. Yashiki, T. Anan, and M. Tsuji: Electron. Lett. 45 (2009) 45.

9) R. Nagarajan, T. Fukushima, J. E. Bowers, R. S. Geels, and L. A. Coldren: Appl. Phys. Lett. 58 (1991) 2326.

10) L. Coldren and S. W. Corzine: Diode Lasers and Photonic Integrated Circuits (John Wiley \& Sons, Inc. 1995) Chap. 5.

11) J. D. Ralston, S. Weisser, I. Esquivias, E. C. Larkins, J.
Rosenzweig, P. J. Tasker, and J. Fleissner: IEEE J. Quantum Electronics 29 (1993) 1648.

12) N. Suzuki, H. Hatakeyama, K. Fukatsu, T. Anan, K. Yashiki, and M. Tsuji : Electron. Lett. 42 (2006) 975.

13) K. Fukatsu, K. Shiba, Y. Suzuki, N. Suzuki, T. Anan, H. Hatakeyama, K. Yashiki, and M. Tsuji : Photon. Tech. Lett. 20 (2007) 909.

14) J. K. Guenter, J. A. Tatum, R. A. Hawthorne III, R. H. Johnson, D. T. Mathes, and B. M. Hawkins: Proc. SPIE 5737 (2005) 20.

15) J. J. Wierer, P. W. Evans, N. Holonyak, Jr., and D. A. Kellogg: Appl. Phys. Lett. 71 (1997) 3468.

16) N. Suzuki, T. Anan, H. Hatakeyama, and M. Tsuji: Appl. Phys. Lett. 88 (2006) 231103.

17) K. Yashiki, N. Suzuki, K. Fukatsu, T. Anan, H. Hatakeyama, and M. Tsuji: Jpn. J. Appl. Phys. 46 (2007) L512.

18) K. Yashiki, N. Suzuki, K. Fukatsu, T. Anan, H. Hatakeyama, and M. Tsuji: IEEE Photon. Tech. Lett. 19 (2007) 1883.

19) T. Anan, N. Suzuki, K. Yashiki, K. Fukatsu, H. Hatakeyama, T. Akagawa, K. Tokutome, and M. Tsuji: Optical Fiber Communication Conf. (OFC), San Diego, February, 2008, OThS5.

20) Y.-C. Chang, C. S. Wang and L. A. Coldren: Electron. Lett. 43 (2007) 1022.

21) P. Westbergh, J. S. Gustavsson, A. Haglund, H. Sunnerud, and A. Larsson: Electron. Lett. 44 (2008) 907.
type-IIトンネルジャンクション (type-II tunnel junction) type-II型半導体へテロ接合を有するトンネル接合。卜 ンネル接合は良く知られるように，順方向バイアスでは 電圧に対し負性抵抗を示す。一方，逆バイアス時にはp 型半導体の価電子帯からn型半導体の伝導帯への電子の 量子トンネル効果のため, 金属のようなオーミック特性 を示し，これを利用して2つのデバイス間の接合や， キャリア変換に用いることが出来る。これらの用途では
抵抗が小さいことが望まれ，さらに光素子への適用に際 しては光吸収が小さいことも必要となるが，低抵抗化と 低吸収化は一般にトレードオフの関係にあり，両立は難 しい. そこでtype-II型の半導体へテロ接合を用いること により，光吸収を抑制しつつ，かつ電子に対するトンネ ル障壁高さも抑制して抵抗を低減するようなバンドライ ンアップを実現している.

(阿南 隆由) 